\title{
Agronomic practices preventing local outbreaks of rice yellow mottle virus disease revealed by spatial autoregressive analysis
}

\author{
Nobuhito Sekiya ${ }^{1}$ (D) $\cdot$ Toru Nakajima $^{1} \cdot$ Nobuaki Oizumi $^{2} \cdot$ Chihiro Kurosawa $^{3} \cdot$ Naswiru Tibanyendela $^{4}$. \\ Mchuno Alfred Peter ${ }^{1,5} \cdot$ Motonori Tomitaka $^{2} \cdot$ Keiko T. Natsuaki ${ }^{3}$
}

Accepted: 18 January 2022 / Published online: 24 February 2022

(C) The Author(s) 2022

\begin{abstract}
Rice yellow mottle virus (RYMV) causes severe rice (Oryza sativa L.) yield loss. It has been endemic to sub-Saharan Africa and Madagascar since 1966. Transmission (plant community level) and long-dispersal (regional and continental scale) models have been established but viral spread in farming communities continues, while the conditions causing local disease outbreaks remain unclear. We hypothesized that local outbreaks, comprising inter-plot virus spread and intra-plot disease aggravation, are significantly associated with individual farmers' attributes and agronomic practices. To test this hypothesis, spatial autoregressive models were constructed using variables collected by visual observation and farmer interviews. Field surveys were conducted during four consecutive cropping seasons from 2011 to 2013 in the Lower Moshi Irrigation Scheme of Kilimanjaro, Tanzania. Our models detected spatial dependence in inter-plot virus spread, but not in intra-plot disease aggravation. The probability of inter-plot virus spread increased with use of the IR64 cultivar (26.9\%), but decreased with straw removal (27.8\%) and crop rotation $(47.7 \%)$. The probability of intra-plot disease aggravation decreased with herbicide application $(24.3 \%)$ and crop rotation (35.4\%). A simple cost-benefit analysis suggested that inter-plot virus spread should be mitigated by cultivar replacement and straw removal. When disease severity is critical, intra-plot disease aggravation should be inhibited by herbicide application, and rice should be rotated with other crops. This is the first study to upscale the spatial autoregressive model from the experimental field level to the farming community level, by obtaining variables through easy-to-implement techniques such as visual observation and farmer interview. Our models successfully identified candidate agronomic practices for the control of RYMV. However, as the causal relationships between agronomic practices and RYMV outbreaks remain unknown, field trials are needed to develop robust control measures.
\end{abstract}

Keywords Farmer interview $\cdot$ Rice production $\cdot$ Spatial autocorrelation $\cdot$ Spatial autoregression $\cdot$ Visual observation $\cdot$ Tanzania

Nobuhito Sekiya

kapinivilage@yahoo.co.jp

1 Graduate School of Bioresources, Mie University, Tsu, Mie 514-8507, Japan

2 Japan International Cooperation Agency (JICA), JICA Tanzania Office, Dar es Salaam 9450, Tanzania

3 Department of International Agricultural Development, Tokyo University of Agriculture, 1-1-1 Sakuragaoka, Setagaya, Tokyo, Japan

4 Department of Crop Science and Horticulture, Sokoine University of Agriculture, Morogoro 3005, Tanzania

5 Kilimanjaro Agricultural Training Centre, Moshi 1241, Tanzania

\section{Introduction}

Rice yellow mottle virus (RYMV, Fig. 1a) is a member of the genus Sobemovirus in the family Solemoviridae (Sõmera et al. 2015). Its host range is restricted to rice (Oryza sativa L.) and a few wild Poaceae. However, it has been endemic in ricegrowing regions of sub-Saharan Africa and Madagascar since its discovery in 1966 near Lake Victoria in Kenya (Bakker 1974; Kouassi et al. 2005).

The characteristic symptoms of RYMV disease are mottling, yellowish leaf streaking (Fig. 1b), decreased tillering (Fig. 1c), shoot stunting (Fig. 1c), and spikelet sterility (Bakker 1970; Fauquet and Thouvenel 1977; Abo et al. 2000). RYMV disease causes 10-100\% yield loss depending on plant age, cultivar susceptibility, and environmental factors (Kouassi et al. 2005). Therefore, RYMV is considered a major 
Fig. 1 Rice yellow mottle virus (RYMV). (a) Electron

micrograph of virus particles. (b) Leaf samples exhibiting characteristic symptoms of infection: yellowish streaking and mottling leaves. (c) Young seedling grown in a pot and naturally infected with RYMV. (d) Ratoon exhibiting characteristic symptoms of infection. (e) Almost all ratoons infected in a plot in the Upper Mabogini system (see aerial photograph, Fig. 2). (f) Greenish and healthy seedlings growing from seeds dropped during the previous harvest (center) flanked by infected ratoons in another Upper Mabogini plot.
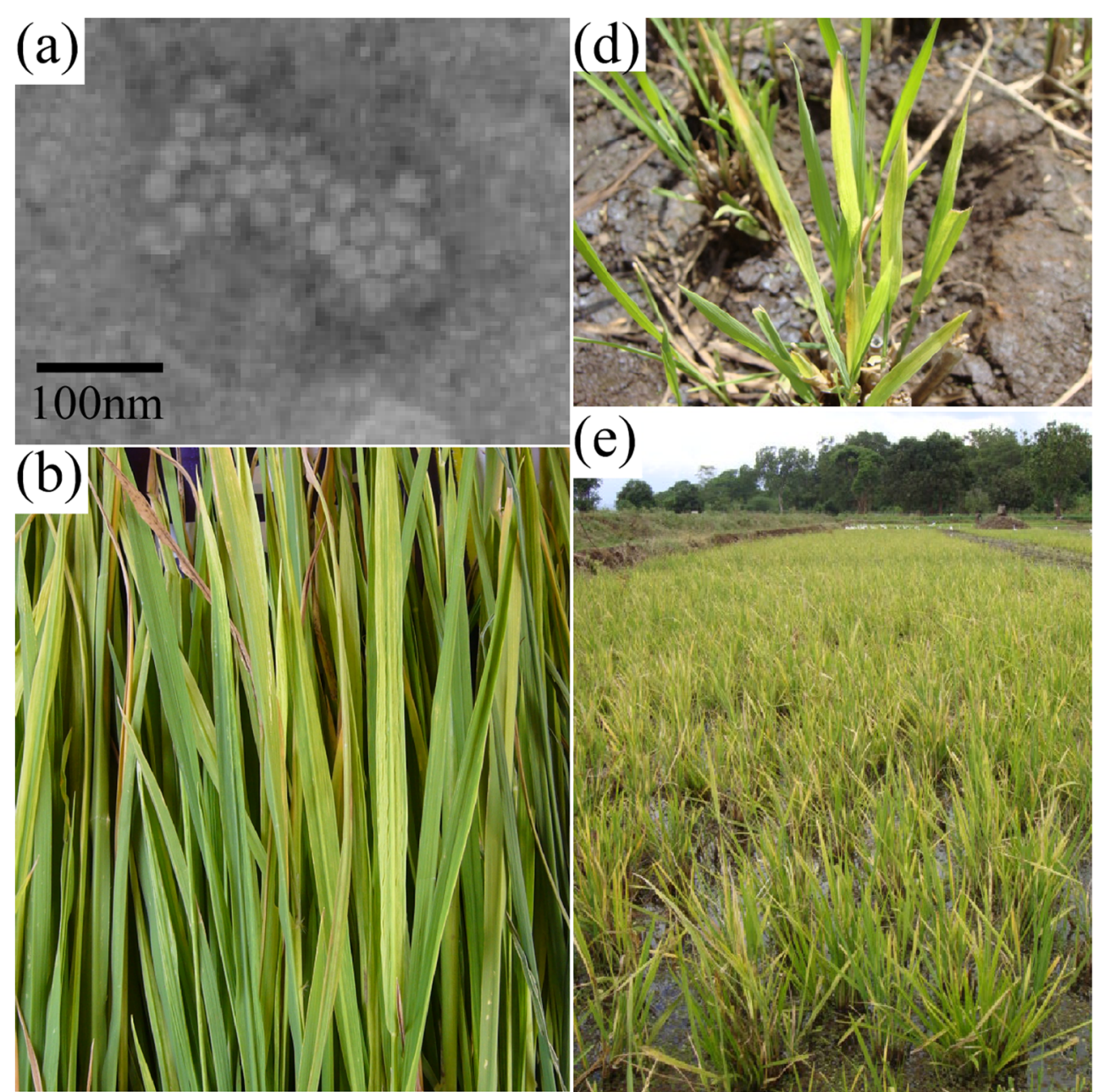

(e)

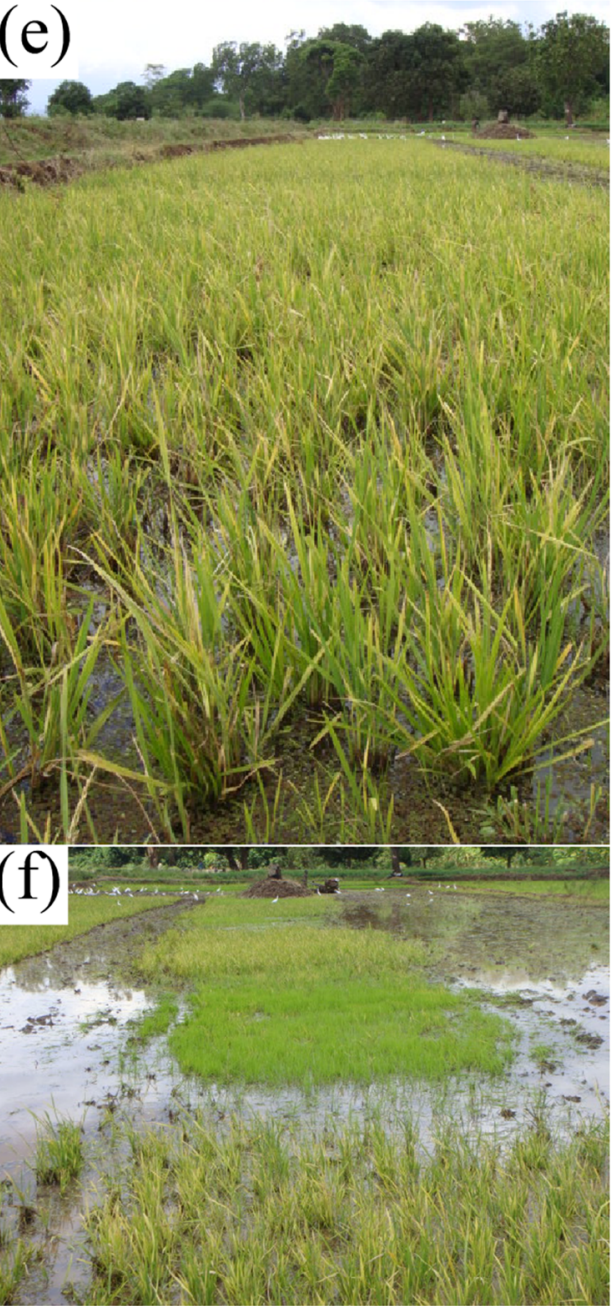

constraint on rice production in sub-Saharan Africa and Madagascar (Savary et al. 2019; Suvi et al. 2019).

The mechanism of RYMV transmission at the plant community level is well established, with epidemiological models proposed (Traoré et al. 2009); in wild reservoirs, rice stubble, and elsewhere in the environment, RYMV is disseminated to rice seedlings via biotic agents such as Chrysomelidae beetles (Bakker 1974). In seedbeds, close spacing facilitates biotic (insect) and abiotic (wind dispersal; Sarra et al. 2004) RYMV transmission. Uprooting, bundling, and transplanting contaminate healthy rice seedlings and disseminate primary infection in the field (Traoré et al. 2006; Traoré et al. 2008; Uke et al. 2014). The virus is transmitted from contaminated soils to healthy transplanted seedlings (Traoré et al. 2008, Sarra 2005), with even a small volume able to transmit infection (Uke et al. 2014). Reverse viral transmission from the field to the environment also occurs via cows, donkeys, and other animals during harvest (Sarra and Peters 2003). Birds also have been implicated in RYMV transmission (Peters et al. 2012). Irrigation, double cropping, and the propagation of high- 
yielding Asian rice cultivars with high susceptibility may also contribute to RYMV spread (Fargette et al. 2006; Trovão et al. 2015).

Phylogeographic analysis has delineated long-distance RYMV dispersal at the regional and continental scales (Traoré et al. 2009). Earlier studies have demonstrated genetic RYMV diversity within related agroecological zones (Konate et al. 1997; N'Guessan et al. 2000). RYMV diversity progressively decreases from East to West Africa (Pinel et al. 2000), with a strong link between genetic and geographic distance (Abubakar et al. 2003). RYMV originated in East Africa, dispersed towards West Africa, and gradually differentiated (Fargette et al. 2004). It has been hypothesized that in a wavelike process, wind-borne vectors spread plant viruses and initiate new outbreaks on the continental scale (Fargette et al. 2006). An analysis of the molecular diversity of RYMV in the Zanzibar archipelago and Madagascar revealed frequent spread over dozens of kilometers. This finding was consistent with the flight range of beetle vectors, which in rare cases may reach hundreds of kilometers (Rakotomalala et al. 2013). The intensity and extent of rice cultivation could be the main determinant of RYMV emergence and spread (Trovão et al. 2015). Nevertheless, this hypothesis was recently challenged (Dellicour et al. 2018).

Short- (plant community) and long- (regional and continental) distance RYMV dispersal has been theoretically modeled. However, the mechanism by which the virus spreads from field to field at the community level is unknown. Thus, the conditions conducive to local disease outbreaks are poorly understood in viral epidemics (Traoré et al. 2009). In Africa, there are patchy distributions of agronomic practices across farming communities (Sekiya et al. 2017; Sekiya et al. 2020; Senthilkumar et al. 2018); this pattern greatly affects viral spread. Interactions among rice farmers in close proximity also help disseminate the virus. RYMV likely spreads more frequently between neighboring than remote plots through biotic and abiotic agents. Therefore, spatial contiguity and heterogeneity are important variables in any investigation of RYMV spread at the farming community level.

Spatial autoregressive models are powerful tools for analyzing the spread of plant disease. They account for spatial contiguity and heterogeneity at the community level. Autologistic models of plant disease spread integrate binary response variables, including disease presence or absence. These models were implicated in a pioneering work on the development of statistical theory (Besag 1972). The autologistic model has been applied to establish the incidence of footrot disease in endive (Besag 1977). It was then integrated with environmental covariates and used to model the influence of soil moisture on Phytophthora epidemics in bell pepper (Gumpertz et al., 1997). The autologistic model has been applied with categorical data, such as a 1-4 disease rating scale (Strauss 1992). It also has been used to assess anthracnose disease in tropical pasture legumes (Smyth et al. 1992).
A spatial autoregressive probit model fitted with management covariates has been applied to evaluate potato leaf roll virus (PLRV) to identify efficacious management options (Marsh et al. 2000). Spatial autoregressive models also have been extensively and empirically tested in social science applications including crime analysis, environmetrics, epidemiology, and public health (Anselin 2010).

The aim of this study was to identify mechanisms underlying short-distance RYMV transmission at the plant community level, as well as long-distance viral dispersal at the regional and continental scales. Here, we tested the hypothesis that the spread of RYMV at the farming community level is associated with agronomic practices used for each plot. To test this hypothesis, we constructed a spatial autoregressive model, using visual diagnosis of RYMV infection as the dependent variable, with farmers' individual attributes and agronomic practices as independent variables. In agronomic studies, spatial autoregressive models have been successful, but limited to smaller-scale field experiments (Florax et al. 2002; Gumpertz et al., 1997; Liu et al. 2015); these models have rarely been employed at the farming community level. The limited use of this analytical tool could be ascribed to the difficulty of obtaining data for larger-scale variables. In this study, we have upscaled the application of spatial autoregressive models from the experimental field to the farming community level by obtaining dependent and independent variables via easyto-implement techniques: visual observation and farmer interviews, respectively. We performed field surveys in the Lower Moshi Irrigation Scheme (LMIS) in Tanzania (Fig. 2). Rice farmers in the region have been practicing basic cultivation techniques such as land preparation (plowing, bundling, and leveling), seedling nursery in seedbeds, transplanting of young seedlings in straight lines, application of basal and topdressing fertilizers, and irrigation using modern water supply facilities (see more details in Sekiya et al. 2017 and Sekiya et al. 2020). IR64 has been the most popular rice cultivar, but TXD306 has been gradually disseminated in the LMIS (Sekiya et al. 2013). Plant residues are routinely removed for use as animal feed and bedding by upland farmers at Mt. Kilimanjaro. Rice farmers have obtained high yields with low incidences of serious disease (Ikegami 1995). RYMV was nonetheless detected by immunological and molecular techniques in rice leaves collected from the LMIS in 2010 (Uke et al. 2015). Thereafter, a growing number of rice farmers complained of plant damage consistent with RYMV infection.

\section{Materials and methods}

\subsection{Lower Moshi Irrigation Scheme}

The LMIS is located in the Moshi rural district of the Kilimanjaro region $\left(3^{\circ} 23^{\prime} 2^{\prime \prime}-3^{\circ} 28^{\prime} 42^{\prime \prime} \mathrm{S}, 37^{\circ} 20^{\prime} 57^{\prime \prime}-37^{\circ} 25^{\prime}\right.$ 14" E, 717-768 masl). The scheme was constructed in 1987 
Fig. 2 Schematic of the Lower Moshi Irrigation Scheme (LMIS). Plots are overlaid on an aerial photograph of LMIS, located in the Moshi rural district of the Kilimanjaro region $\left(3^{\circ} 23^{\prime} 2^{\prime \prime}-\right.$ $3^{\circ} 28^{\prime} 42^{\prime \prime} \mathrm{S}, 37^{\circ} 20^{\prime} 57^{\prime \prime}-37^{\circ} 25^{\prime}$ $14^{\prime \prime}$ E, 717-768 masl). The scheme extends $\sim 12 \mathrm{~km}$ from NW to SE, with a total area of approximately $1100 \mathrm{ha}$. LMIS introduces water from the Njoro and Rau rivers flowing from Mt. Kilimanjaro to irrigate the Mabogini (MS) and Rau systems (RS), respectively. Traditionally, MS is further divided into the Upper and Lower Mabogini systems. For water-supply planning, LMIS is divided into 45 blocks each of which consists of 39 to 140 plots of approximately 0.3 ha. Until the early 1990 s, the irrigation water was distributed evenly throughout the scheme so that the cropping intensity did not vary from one block to another. Due to the collapse of water the management system, however, the blocks upstream started using more water than those downstream. Generally, rice plants were grown twice a year in UM and once in 1 to 2 years in the other areas.

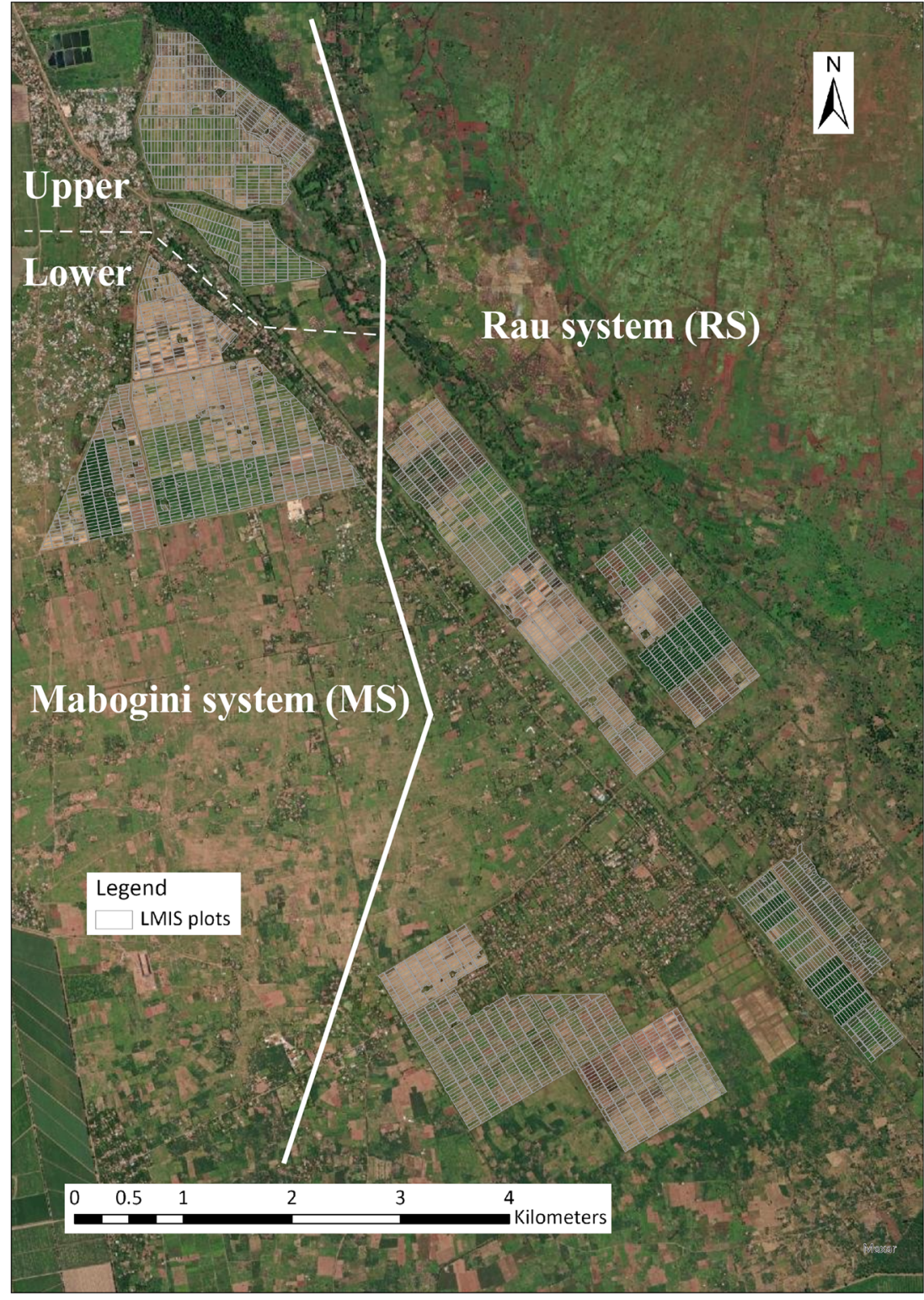

using financial aid from Japan. It extends for $\sim 12 \mathrm{~km}$ from NW to SE (Fig. 2). Its total area is 1100 ha, divided into 45 blocks, each consisting of 39-140 plots. Each plot area is $\sim 0.3$ ha. From the late 1980 s to the early $1990 \mathrm{~s}$, the scheme was stewarded with a water distribution plan and communal field management under the supervision of the Kilimanjaro region. However, the system collapsed after management was transferred from the Kilimanjaro region to the farmers' group.

Upstream farmers in Upper Mabogini system began annual rice double-cropping between December and April (rainy season) and between June and October (dry season). By the late 1990s, it became difficult for some downstream farmers in the Lower Mabogini and Rau systems to grow rice, even only once per year. Downstream farmers who are unable to grow rice during the rainy season must grow maize (Zea mays L.) instead, which requires supplemental irrigation. IR54 was the most popular rice cultivar in the 1980s and 1990s. However, it was replaced by IR64 in the 2000s (Sekiya et al. 2013). TXD306 was then bred by the Tanzanian Research Institute and has been gradually disseminated in LMIS.

\subsection{Field survey}

A field survey was conducted in the first (July-December, 2011, dry), second (December 2011-June 2012, rainy), third (July-December 2012, dry), and fourth (January-June 2013, rainy) cropping seasons. Two surveyors were selected from the LMIS management office and Kilimanjaro Agricultural Training Centre (KATC) to review RYMV literature and photographs. They practiced visual observation to judge whether 
rice plant leaves were yellow because of RYMV infection or other factors such as nutrient deficiency. The surveyors eventually learned to identify RYMV infection readily by the characteristic yellow leaf mottling it causes. The surveyors visited the area 1 month after transplanting. The timings of transplanting and visits differed between plots by $\leq 1$ month. Therefore, the surveyors visited plots separately on the basis of plant growth. First, a surveyor would inspect the plot to evaluate the occurrence of RYMV at a single point. Second, a surveyor would walk slowly through the plot and thoroughly examine it for RYMV occurrence. To confirm the accuracy of these observations, 323 samples were collected from all plots visually judged to be infected in the first and second cropping seasons. Two or three leaves were collected from each of two or three infected rice plants, cut into $2-3-\mathrm{cm}$ segments, and mixed thoroughly, placed in paper envelopes, and air-dried. RYMV was detected by double antibody sandwich ELISA (DASELISA) (Clark and Adams 1977) with a kit containing polyclonal antibodies (NEOGEN Europe Ltd., Ayr, UK). A total of 265 samples were RYMV-positive, confirming the accuracy of visual observation; therefore, the final field survey was only visual in the third and fourth cropping seasons. In total, the surveyors visited $1337,874,1170$, and 835 plots in the first, second, third, and fourth cropping seasons, respectively, for visual detection of RYMV infection. Infection was then calculated for the plot level from the ratio of RYMV-infected rice hills to the total number of hills per plot. The RYMV status classifications were $0 \%, 1-10 \%, 11-50 \%$, and $\geq 51 \%$.

\subsection{Farmer interviews}

Questionnaire-based surveys were conducted between July (transplanting period) and December (harvesting period) 2011, in the first cropping season, and between May (heading period) and June (harvesting period) 2012, in the second cropping season. As some LMIS landlords entrusted rice cultivation to their employees, we expected that financial and temporal costs would have to be incurred to locate absent landlords. Thence, the LMIS management office selected landlords directly engaged in rice cultivation. During this selection process, the number of target landlords, and hence plots, were less than the numbers of fieldsurveyed plots $(1337,874,1170$, and 835 plots in the first, second, third, and fourth cropping season, respectively). Thereafter, some landlords were visited individually, and groups of other landlords were met at events such as church services. Landlords were queried about their age and standard agronomic practices, including soil preparation, seedling propagation, fallow period, rice-maize farming systems, insecticide application, plant residue treatment, cultivar types, and crop yield over the past 3 years. Some landlords were unable to grow rice either in the first nor second cropping season due to either fallow periods or maize cultivation in crop rotation. Moreover, many landlords were still practicing rice cultivation when they were queried about field practices, making it difficult to assess field practices in either the first or second cropping seasons. Therefore, landlords were requested to state the practices that they had conducted in the past few seasons in their plots as "standard agronomic practices". Interviewee contact information was collected in the event that contradictory data had to be clarified at a later time via telephone. After this process, 221 landlords with 424 plots were then selected from across LMIS for further analysis. Descriptive statistics of the initially selected plots by landlord (the number of plots per landlord) were 1.92, 1.87, 1 and 13 (mean, standard deviation, minimum value, and maximum value, respectively). Although the maximum number of plots per landlord was as large as 13 , the standard deviation was as small as 1.87 , indicating that the number of plots cultivated per farmer was relatively homogeneous.

\subsection{Data analysis}

To analyze the relationship between RYMV status and agronomic practices, the spatial autoregressive model described by LeSage and Pace (2009) and Wilhelm and de Matos (2013) was applied to field survey and farmer interview data. The model is represented by the equation:

$$
y^{*}=\rho W y^{*}+X \beta+\varepsilon, \varepsilon \sim N\left(0, \sigma_{\varepsilon}^{2} I_{n}\right)
$$

where $y^{*}$ is a latent variable related to a binary outcome variable $y_{i}, y_{i}=1$ if $y_{i}^{*} \geq 0$, and $y_{i}=0$ if $y_{i}^{*}<0$. Because this is the first study to analyze the relationships between RYMV status and agronomic practices, dependent and independent variables that are predetermined or theoretically appropriate do not exist; therefore, the selection of those variables was exploratory.

Two variables, RYMV infection and RYMV aggravation, were used as dependent variables. Infection indicates whether or not a plot was infected at a given time or period, while aggravation represents whether the initial RYMV status of a plot got worse after a while. Here, RYMV infection was estimated in two different ways:

1) $y_{i}=1$ if $>1 \%$ of the rice hills in plot $i$ was observed in the first cropping seasons; otherwise, $y_{i}=0$ (model 1), and

2) $y_{i}=1$ if $>1 \%$ of the rice hills in plot $i$ was observed in one in four cropping seasons; otherwise, $y_{i}=0$ (model 2).

Aggravation of RYMV infection was estimated in two different ways:

1) $y_{i}=1$ if the infection rate of plot $i$ increased from the first to the fourth cropping seasons irrespective of the infection rate in the second and third cropping seasons; otherwise, $y_{i}=0$ (model 3). For example, RYMV spread was taken 
to be aggravated if $<1 \%$ of the rice hills were infected in the first season and $>1 \%$ of the rice hills were infected in the fourth season.

2) $y_{i}=1$ if the infection rate of plot $i$ in the first cropping season increased in one in the subsequent three cropping seasons, $y_{i}=0$ otherwise (model 4 ). For example, RYMV spread would be scored as aggravated if $<1 \%$ of the rice hills were infected in the first season, and $1-10 \%$ of the rice hills were infected in the second season while $<1 \%$ of rice hills were infected in the third and fourth seasons.

The parameter $\rho$ captures spatial plot dependence. When $\rho$ is positive, a plot with nearby infected plots tends to be infected itself and vice versa. $W$ is the spatial weight matrix representing spatial contiguity among plots. As shown in Figs. 3 and 4, the plots were distributed more densely in the northern part (Upper Mabogini system) and more sparsely in the middle and southern parts (Lower Mabogini and Rau systems). In this setting, it should be inappropriate to create a nearest neighbor-type weight matrix, since some plots in the distance of a target plot could not be regarded to be contiguous in the middle or southern parts. Furthermore, plots were not necessarily adjacent in the northern part, making it once again inappropriate to create a contiguity-based weighting matrix. It is therefore straightforward to construct a spatial weight matrix based
Fig. 3 Distribution of plots (424 owned by 221 landlords) initially selected across the Lower Moshi Irrigation Scheme (LMIS) for data collection. Blue plot, dependent variable is 0 ; red plot, dependent variable is 1 ; gray plot, missing values or an outlier excluded from model estimations. (a) Distribution of a dependent variable (whether or not rice yellow mottle virus [RYMV] infection was observed in the first cropping season) used in model 1 (201 plots, 118 landlords).

(b) Distribution of a dependent variable (whether or not RYMV infection was observed in one in four cropping seasons) used in the estimation of model 2 (228 plots, 139 landlords). (c) Distribution of a dependent variable (whether or not RYMV infection status in the first cropping season aggravated in the fourth cropping season) used in the estimation of model 3 (128 plots, 87 landlords).

(d) Distribution of a dependent variable (whether or not RYMV infection status in the first cropping season aggravated in one of the subsequent three cropping seasons) used in the estimation of model 4 (128 plots, 87 landlords).

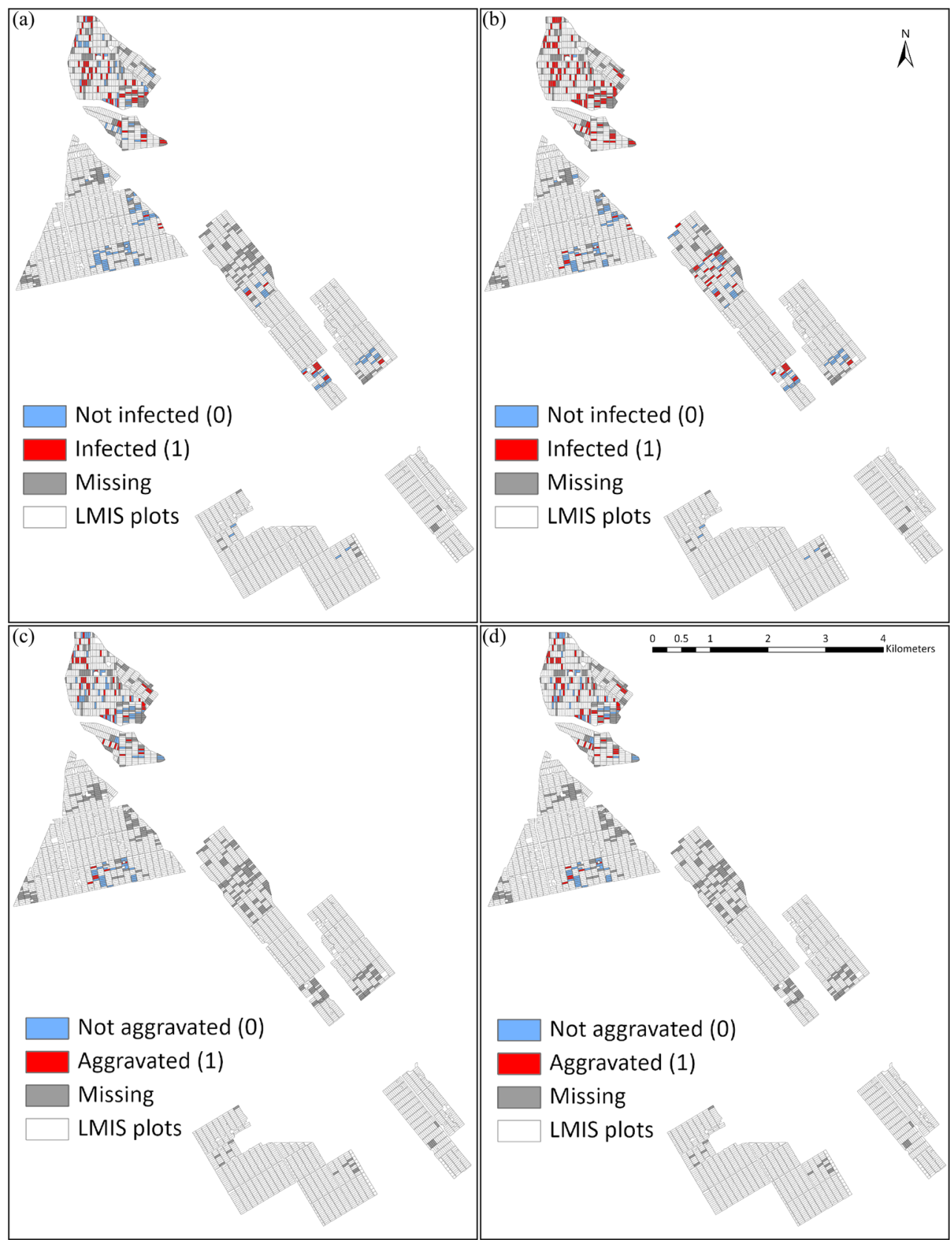


Fig. 4 Rice yellow mottle virus (RYMV) infection status visually diagnosed in the Lower Moshi Irrigation Scheme (LMIS) between July 2011 and December 2013. Blue plot, no infected hill; yellow plot, $1-10 \%$ of hills infected; pink plot, $11-50 \%$ of hills infected; red plot, more than $51 \%$ of hills infected. Grey plot: plots with missing values or an outlier excluded from the model estimations. (a) RYMV infection status in the first cropping season (July-December, 2011, dry).

(b) RYMV infection status in the second cropping season (December 2011-June 2012, rainy). (c) RYMV infection status in the third (July-December 2012, dry) cropping season. (d) RYMV infection status in the fourth cropping season (January-June 2013, rainy)

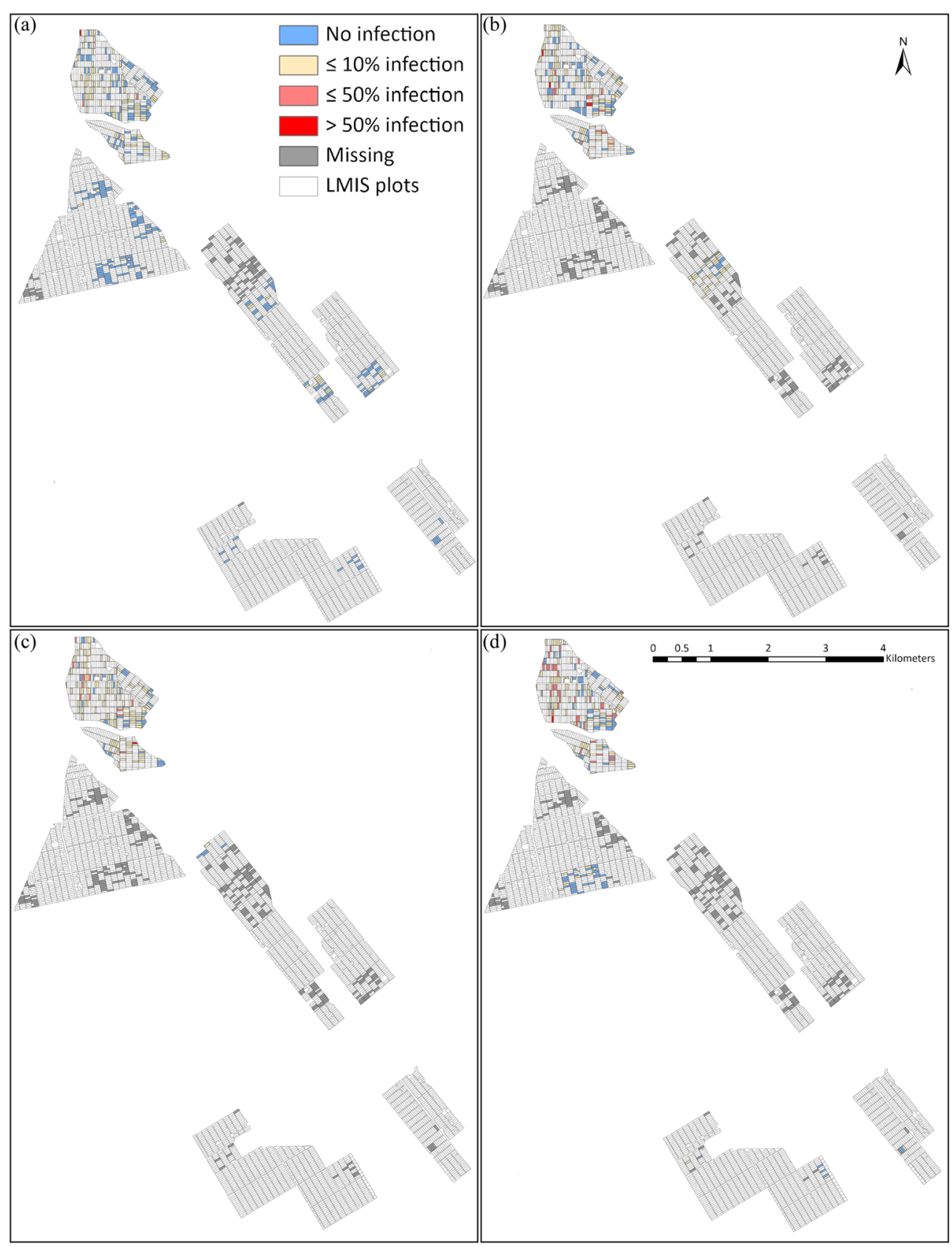

on distance metrics; plots within a specified, small distance from a target plot were considered contiguous. Then, the radius distance spatial weight matrix was employed to represent contiguity in this study. An element $W_{\mathrm{ij}}=1$ if plot $j$ is located within a specified distance from plot $i$. Otherwise, $W_{\mathrm{ij}}=0$. Sensitivity was tested by applying different radii. For our estimations, the weight matrix was row-standardized; the sum of all row elements was set to unity.

$X$ is an independent variable matrix including the aforementioned farmer attributes and standard agronomic practices. Some of the initially selected 221 landlords failed to provide some independent variables, while one of the two dependent variables was not obtained for some of the initially selected 424 plots. Moreover, the age of one landlord was reported to be more than 100 years. Then, RYMV infection was estimated using 201 samples (plots) owned by 118 landlords in model 1, 228 plots owned by 139 landlords in model 2, and 128 plots owned by 87 landlords in models 3 and 4, after excluding those with missing values and the outlier. Descriptive statistics of the plots by landlord are 1.70,1.69, 1, and 13 in model 1; $1.64,1.61,1$, and 13 in model 2; and 1.47, 1.08, 1, and 7 in models 3 and 4 (mean, standard deviation, minimum value, and maximum value, respectively). Means and standard deviations of the plots by landlord in models 1 (1.70 and 1.69) and 2 (1.64 and 1.61) were relatively small but still comparable to 
those in the initially selected plots (1.92 and 1.87), suggesting little bias in the sampling of landlords from the initially selected 221 landlords. Distributions of the estimated plots in models 1 (Fig. 3a) and 2 (Fig. 3b) were not largely heterogeneous among the initially selected 424 plots, suggesting little bias in plot sampling. However, mean and standard deviation of the plots by landlord in models 3 and 4 (1.47 and 1.08) were small compared to those in the initially selected plots (1.92 and 1.87); the estimated plots in these two models were relatively heterogeneously distributed in the Upper Mabogini system (Fig. $3 \mathrm{c}$ and d), suggesting that the estimated plots in models 3 and 4 may represent landlords with smaller numbers of plots in Upper Mabogini system. Therefore, estimated results should be interpreted with caution.

$\beta$ is a parameter vector. The error term $\varepsilon$ is assumed to be normally distributed with variance $\sigma_{\varepsilon}^{2} I_{n}$ where $I_{n}$ is a unit matrix. The term $\sigma_{\varepsilon}^{2}$ is conventionally set to unity for identification (LeSage and Pace 2009). All parameters were estimated by the Bayesian method with Markov Chain Monte Carlo (MCMC) sampling and the "spatialprobit" package in R v. 3.5.3 (R Core Team, Vienna, Austria). Details of the estimation procedure may be found in works of LeSage and Pace (2009) and Wilhelm and de Matos (2013). Here, the prior distributions of $\rho$ and $\beta$ were $\operatorname{Uni}(-1,1)$ and $N(c, T)$, respectively; $c$ is the prior mean of multivariate normal distribution, and $T$ is the prior variance. Because no information was available on prior distributions, the prior of $\rho$ was considered uninformative, and the theoretical range of $\rho$ between -1 and 1 was employed. The prior of $\beta$ was also considered uninformative, and $c$ was treated as a vector of zeros, and the diagonal elements of $T$ were set at $1 \mathrm{e}+12$. In the MCMC sampling, 10,000 samples were drawn with 5000 burn-in samples. The trace plots for all parameters converged after 5000 burn-ins in the estimations of RYMV infection and aggravation.

\section{Results and discussion}

\subsection{Field survey and farmer interview}

RYMV infection in each cropping season is shown in Fig. 4. Infection was relatively dense in the northern part (Upper Mabogini system) and sparse in the middle (Lower Mabogini) and southern (Rau system) parts throughout all four cropping seasons. In the first cropping season, RYMV was almost completely confined in Upper Mabogini system, where the infection ratios were low $(1-10 \%)$ in most cases, with a limited number of plots infected in the Lower Mabogini and Rau systems (Fig. 4a). In the second cropping season, an increased number of plots were found to be moderately (11$50 \%$ ) and highly (>50\%) infected in Upper Mabogini system, with viral spread in the northern part of Rau system (Fig. 4b). In the third cropping season, the infection appeared to have diminished across the LMIS; highly infected plots $(>50 \%)$ almost disappeared in the Upper Mabogini system, with only a limited number of plots infected (1-10\%) in the Rau system (Fig. 4c). In the fourth cropping season, however, RYMV appeared to have regained momentum across the entire LMIS; the numbers of moderately (11-50\%) and highly $(>50 \%)$ infected plots increased again in Upper Mabogini, and the infection was found in the western and southern parts of the Rau system (Fig. 4d).

Descriptive statistics for the dataset collected from field surveys and farmer interviews are shown in Table 1. The mean infection rates were $\sim 0.37$ and $\sim 0.6$ for the first and all four cropping seasons, respectively. The infection rate increased from the first to fourth cropping seasons in $~ 37 \%$ of all plots and from the first to one of four cropping seasons in $53 \%$ of all plots. These observed infection and aggravation rates were consistent with farmer complaints that RYMV had rapidly spread across LMIS during the survey period.

The average farmer age was 54 years, and the average plot size was $\sim 0.28$ ha. As few as $41 \%$ of all plots were plowed. As the transfer of scheme management dissolved joint tractor ownership, most farmers had to hire private tractor operators. To reduce this expense, some farmers obviated plowing by using puddle irrigation. Upstream farmers using double-cropping kept their plots wet throughout the year and omitted plowing because of excessive water. About $42 \%$ of the farmers purchased rice seeds, either to introduce new cultivars or to purify existing cultivars by renewing their seeds.

Approximately $73 \%$ of all farmers participated in communal nurseries, which had been introduced immediately after scheme construction. They supported uniform rice plant growth across the scheme and effective water distribution planning. The transfer of scheme management had initially reduced the proportion of farmers involved in the communal nursery; however, their participation gradually increased because harvest synchronization attracted more traders to the scheme. IR64 was still grown on $\sim 80 \%$ of all plots, but TXD306 was slowly disseminated across the scheme.

The average paddy yield was $7.9 \mathrm{t} \mathrm{ha}^{-1}$, far surpassing the national average of $2.1 \mathrm{t} \mathrm{ha}^{-1}$ (Sekiya et al. 2017; MAFC (Ministry of Agriculture Food Security and Cooperatives), 2009). Modern irrigation infrastructure includes a flat land surface for smooth water flow (Ikegami 1995) and widespread adoption of basic cultivation techniques (Sekiya et al. 2020). These practices have helped increase crop yields. After harvest, plant residues such as straw were removed from $\sim 25 \%$ of all plots. In Tanzania, plant residues are left in the rice fields after harvest and incorporated into the soil before puddling water is introduced. However, upland farmers at Mt. Kilimanjaro use LMIS straw as animal feed and bedding, so plant residues are removed from a substantial proportion of the plots in 
Table 1 Descriptive statistics of data collected from field surveys of rice yellow mottle virus (RYMV) infection and farmer interviews. SD: standard deviation; Min: minimum value; Max: maximum value; Obs.: number of observations; Model 1: whether or not RYMV infection was observed in the first cropping season (see Table 2); Model 2: whether or not RYMV infection was observed in one of four cropping seasons (see
Table 3); Model 3: whether or not RYMV infection status in the first cropping season was aggravated in the fourth cropping season (see Table 4); Model 4: whether or not RYMV infection status in the first cropping season was aggravated in one of the subsequent three cropping seasons (see Table 5).

\begin{tabular}{|c|c|c|c|c|c|c|}
\hline Variable & & Mean & SD & Min & Max & Obs. \\
\hline \multirow[t]{4}{*}{ Dependent } & RYMV infection (model 1) & 0.372 & 0.487 & 0 & 1 & 349 \\
\hline & RYMV infection (model 2) & 0.614 & 0.487 & 0 & 1 & 389 \\
\hline & RYMV aggravation (model 3) & 0.370 & 0.498 & 0 & 1 & 227 \\
\hline & RYMV aggravation (model 4) & 0.531 & 0.500 & 0 & 1 & 228 \\
\hline \multirow[t]{10}{*}{ Independent } & Farmer age & 54.322 & 13.813 & 22 & 88 & 304 \\
\hline & Plot size (ha) & 0.281 & 0.066 & 0.030 & 0.750 & 347 \\
\hline & Plowing & 0.413 & 0.494 & 0 & 1 & 315 \\
\hline & Seed purchase & 0.417 & 0.494 & 0 & 1 & 379 \\
\hline & Communal nursery & 0.725 & 0.447 & 0 & 1 & 404 \\
\hline & IR64 & 0.803 & 0.398 & 0 & 1 & 351 \\
\hline & Herbicide application & 0.465 & 0.500 & 0 & 1 & 344 \\
\hline & Paddy yield $\left(\mathrm{t} \mathrm{ha}^{-1}\right)$ & 7.875 & 1.481 & 1.400 & 12.444 & 323 \\
\hline & Straw removal & 0.251 & 0.434 & 0 & 1 & 342 \\
\hline & Crop rotation & 0.542 & 0.499 & 0 & 1 & 347 \\
\hline
\end{tabular}

Table 2 Posterior means of each estimate and marginal effects of changes in each independent variable obtained from spatial autoregressive model 1 for rice yellow mottle virus (RYMV) infection in season 1 in the Lower Moshi Irrigation Scheme (LMIS), Tanzania. Mean (Posterior means): posterior mean of an estimate; 95\% LB: lower bound of the $95 \%$ credible interval of an estimate; $95 \%$ UB: upper bound of the $95 \%$ credible interval of an estimate; Mean (Marginal effect): posterior mean of a variable effect; Rho: parameter of spatial dependence; Obs.: number of observations. $90 \%$ LB and $90 \%$ UB for posterior mean of IR64 are 0.037 and 1.017 , respectively while $90 \%$ LB and $90 \%$ UB for marginal effect of IR64 are 0.014 and 0.413 , respectively. $90 \% \mathrm{LB}$ and $90 \% \mathrm{UB}$ for posterior mean of straw removal are -0.952 and -0.025 , respectively while $90 \% \mathrm{LB}$ and $90 \% \mathrm{UB}$ for marginal effect of straw removal are -0.382 and -0.009 , respectively.

\begin{tabular}{|c|c|c|c|c|c|c|}
\hline & \multicolumn{3}{|c|}{ Posterior means } & \multicolumn{3}{|c|}{ Marginal effect } \\
\hline & Mean & 95\% LB & $95 \% \mathrm{UB}$ & Mean & 95\% LB & $95 \% \mathrm{UB}$ \\
\hline Intercept & 0.737 & -1.224 & 2.698 & & & \\
\hline Age & -0.022 & -0.038 & -0.006 & -0.008 & -0.015 & -0.002 \\
\hline Plot size (ha) & -2.929 & -6.678 & 0.754 & -1.135 & -2.714 & 0.287 \\
\hline Plowing & -0.251 & -0.708 & 0.208 & -0.097 & -0.285 & 0.083 \\
\hline Seed purchase & 0.599 & 0.153 & 1.048 & 0.234 & 0.056 & 0.446 \\
\hline Communal nursery & 0.119 & -0.481 & 0.728 & 0.047 & -0.186 & 0.294 \\
\hline IR64 & 0.522 & -0.049 & 1.121 & 0.203 & -0.019 & 0.461 \\
\hline Herbicide application & 0.161 & -0.295 & 0.615 & 0.061 & -0.120 & 0.240 \\
\hline Paddy yield ( $\mathrm{tha}^{-1}$ ) & 0.086 & -0.057 & 0.234 & 0.034 & -0.021 & 0.098 \\
\hline Straw removal & -0.488 & -1.056 & 0.065 & -0.189 & -0.424 & 0.026 \\
\hline Crop rotation & -0.788 & -1.383 & -0.200 & -0.298 & -0.492 & -0.088 \\
\hline Rho & 0.380 & 0.103 & 0.619 & & & \\
\hline Obs. & 201 & & & & & \\
\hline
\end{tabular}


LMIS. During water shortages, a maize (Zea mays L.) rotation was grown under upland conditions (crop rotation) in $54 \%$ of all plots.

\subsection{Spatial contiguity of RYMV infection}

A spatial autoregressive model was constructed for model 1 from visual examinations of RYMV infection in the first cropping season and farmer interviews. Posterior means and 95\% credible intervals for each estimate are shown in Table 2. Spatial dependence $(\rho)$ was detected for RYMV infection. A sensitivity analysis of the radius setting in the spatial weight matrix $(W)$ was conducted by increasing the radius from 0.1 to $1.0 \mathrm{~km}$ at $0.1-\mathrm{km}$ intervals; $\rho$ values were positive, and the $95 \%$ credible interval contained no zero up to radii of $0.4 \mathrm{~km}$. However, the $\rho$ values became "nonsignificant" at radii equal to or greater than 0.5 . Hence, a plot located within $\sim 0.4 \mathrm{~km}$ of any RYMV-infected plot was susceptible to RYMV infection in the first cropping season.

The probability of infection in the first cropping season was increased for plots grown with purchased seeds. When estimated with $90 \%$ credible intervals, the probability was increased for plots with the IR64. In contrast, the probability of infection was decreased for crops grown by elder farmers and when rice straw was removed. With $90 \%$ credible intervals, the probability also was lower when crops were rotated.

The marginal effects on infection associated with each independent variable are also shown in Table 2. The combined direct and indirect effects represent the total marginal effects. Direct marginal effects indicated changes in infection caused by a marginal change in an independent variable when the means of other independent variables were considered. Indirect marginal effects capture effects of the spatial dependence of RYMV infection. While statistical significance is not applicable in Bayesian estimations, nevertheless, a marginal effect is considered to be statistically significant when the $95 \%$ confidence interval of the marginal effect contains no zero.

Our estimation indicated that seed purchase and preferential IR64 production could increase the probability of infection by $23.4 \%$ and $20.3 \%$, respectively. In contrast, 1 -year increase in age, straw removal, and crop rotation decreased the probability of infection by $0.8 \%, 18.9 \%$, and $29.8 \%$, respectively. These results strongly suggest that inter-plot spread (RYMV infection) in the first cropping season is associated with farmer agronomic practices and experiences.

Another spatial autoregressive model was constructed for model 2, in which the dependent variable was whether or not a plot had been infected in at least one of the four cropping seasons. Posterior means and 95\% credible intervals for each estimate are shown in Table 3. Spatial dependence $(\rho)$ was detected for RYMV infection, as was the case for model 1. A sensitivity analysis of the radius setting in the spatial weight matrix found that plots located within $\sim 0.8 \mathrm{~km}$ of any infected plot were susceptible to infection. This "susceptible radius" was longer than the $0.4 \mathrm{~km}$ estimated for model 1 . The probability of infection was increased for plots with high-yield and grown with IR64. In contrast, the probability of infection was decreased for plots in which rice straw was removed and crops were rotated. The marginal effect estimates indicated that preferential IR64 production and an increase in paddy yield by $1 \mathrm{t} \mathrm{ha}^{-1}$ could increase the probability of RYMV infection by $26.9 \%$ and $6.2 \%$, respectively. In
Table 3 Posterior means of each estimate and marginal effects of changes in each independent variable obtained from spatial autoregressive model 2 for rice yellow mottle virus (RYMV) infection observed between the first and fourth cropping seasons in the Lower Moshi Irrigation Scheme (LMIS), Tanzania. Mean (posterior means): Posterior mean of an estimate; $95 \%$ LB lower bound of the $95 \%$ credible interval of an estimate; $95 \%$ UB: upper bound of the $95 \%$ credible interval of an estimate; Mean (marginal effect): posterior mean of a variable effect; Rho: parameter of spatial dependence; Obs.: number of observations.

\begin{tabular}{llllllll}
\hline & \multicolumn{2}{l}{ Posterior means } & & \multicolumn{2}{l}{ Marginal effect } \\
\cline { 2 - 3 } & Mean & $\mathbf{9 5 \%} \mathbf{~ L B}$ & $\mathbf{9 5 \%} \mathbf{~ U B}$ & & Mean & $\mathbf{9 5 \%} \mathbf{~ L B}$ & $\mathbf{9 5 \%}$ UB \\
\hline Intercept & 1.482 & -1.232 & 4.438 & & & \\
Age & -0.013 & -0.032 & 0.005 & & -0.003 & -0.007 & 0.001 \\
Plot size (ha) & -3.516 & -9.015 & 1.131 & & -0.801 & -2.109 & 0.252 \\
Plowing & -0.103 & -0.673 & 0.447 & & -0.023 & -0.155 & 0.101 \\
Seed purchase & 0.162 & -0.401 & 0.714 & & 0.035 & -0.096 & 0.156 \\
Communal nursery & -1.086 & -2.812 & 0.458 & & -0.249 & -0.676 & 0.104 \\
IR64 & 1.196 & 0.496 & 1.927 & & 0.269 & 0.118 & 0.435 \\
Herbicide application & 0.163 & -0.429 & 0.753 & & 0.037 & -0.095 & 0.178 \\
Paddy yield (t ha ${ }^{-1}$ ) & 0.273 & 0.089 & 0.465 & & 0.062 & 0.021 & 0.107 \\
Straw removal & -1.229 & -2.017 & -0.490 & & -0.278 & -0.470 & -0.111 \\
Crop rotation & -2.140 & -3.164 & -1.224 & & -0.477 & -0.662 & -0.323 \\
Rho & 0.306 & 0.034 & 0.548 & & & & \\
Obs. & 228 & & & & & \\
\hline
\end{tabular}


Table 4 Posterior means of each estimate and marginal effects of changes in each independent variable obtained from spatial autoregressive model 3 for rice yellow mottle virus (RYMV) aggravation in the Lower Moshi Irrigation Scheme (LMIS), Tanzania. Mean (Posterior means): posterior mean of an estimate; 95\% LB: lower bound of the $95 \%$ credible interval of an estimate; 95\% UB: upper bound of the $95 \%$ credible interval of an estimate; Mean (Marginal effect): posterior mean of a variable effect; Rho: parameter of spatial dependence; Obs.: number of observations.

\begin{tabular}{|c|c|c|c|c|c|c|}
\hline & \multicolumn{3}{|c|}{ Posterior means } & \multicolumn{3}{|c|}{ Marginal effect } \\
\hline & Mean & $95 \% \mathrm{LB}$ & $95 \% \mathrm{UB}$ & Mean & $95 \% \mathrm{LB}$ & $95 \% \mathrm{UB}$ \\
\hline Intercept & 0.182 & -1.876 & 2.274 & & & \\
\hline Age & 0.004 & -0.014 & 0.022 & 0.002 & -0.005 & 0.008 \\
\hline Plot size (ha) & 0.686 & -2.877 & 4.097 & 0.241 & -1.115 & 1.490 \\
\hline Plowing & 0.118 & -0.391 & 0.626 & 0.043 & -0.145 & 0.237 \\
\hline Seed purchase & -0.284 & -0.789 & 0.232 & -0.104 & -0.311 & 0.083 \\
\hline Communal nursery & -0.105 & -0.702 & 0.483 & -0.038 & -0.258 & 0.179 \\
\hline IR64 & 0.370 & -0.262 & 1.025 & 0.133 & -0.099 & 0.384 \\
\hline Herbicide application & -0.668 & -1.197 & -0.146 & -0.243 & -0.476 & -0.053 \\
\hline Paddy yield $\left(\mathrm{t} \mathrm{ha}^{-1}\right)$ & -0.037 & -0.186 & 0.110 & -0.013 & -0.069 & 0.042 \\
\hline Straw removal & 0.043 & -0.587 & 0.677 & 0.016 & -0.216 & 0.256 \\
\hline Crop rotation & -0.995 & -1.803 & -0.236 & -0.354 & -0.639 & -0.091 \\
\hline Rho & 0.096 & -0.329 & 0.457 & & & \\
\hline Obs. & 128 & & & & & \\
\hline
\end{tabular}

contrast, straw removal and crop rotation decreased the probability of RYMV infection by $27.8 \%$ and $47.7 \%$, respectively.

The two models commonly disclosed that inter-plot virus diffusion is enhanced by IR64 cultivation, but mitigated by removing plant residues and practicing crop rotation. The susceptible radii $(0.4$ or $0.8 \mathrm{~km})$ detected by the two models lie within the recorded flight range of beetle vectors (Rakotomalala et al. 2013). Hence, beetles may contribute to inter-plot RYMV spread, especially during plant growth (Bakker 1974). IR64 has been used as a susceptibility check in several RYMV-resistant cultivar breeding programs (Rakotomalala et al. 2008; Ndikuryayo et al. 2020; Pidon et al. 2017). The adoption of IR64 might increase RYMV susceptibility in the presence of beetles. As post-harvest animal grazing is a common practice in LMIS, cattle and donkeys feeding on straw and rice stubble might also contribute to inter-plot dissemination (Sarra and Peters 2003; Traoré et al. 2009). Post-harvest animal grazing and, by extension, inter-plot RYMV spread, could be reduced by removing plant residue and practicing crop rotation.

\subsection{Spatial contiguity of RYMV aggravation}

A spatial autoregressive model was constructed for model 3, in which RYMV aggravation was estimated based on whether or not the infection rate in the first season had
Table 5 Posterior means of each estimate and marginal effects of changes in each independent variable obtained from spatial autoregressive model 4 for rice yellow mottle virus (RYMV) aggravation in the Lower Moshi Irrigation Scheme (LMIS),

Tanzania. Mean (Posterior means): posterior mean of an estimate; 95\% LB: lower bound of the $95 \%$ credible interval of an estimate; 95\% UB: upper bound of the $95 \%$ credible interval of an estimate; Mean (Marginal effect): posterior mean of a variable effect; Rho: parameter of spatial dependence; Obs.: number of observations.

\begin{tabular}{|c|c|c|c|c|c|c|}
\hline & \multicolumn{3}{|c|}{ Posterior means } & \multicolumn{3}{|c|}{ Marginal effect } \\
\hline & Mean & $95 \% \mathrm{LB}$ & $95 \% \mathrm{UB}$ & Mean & $95 \% \mathrm{LB}$ & $95 \% \mathrm{UB}$ \\
\hline Intercept & -0.456 & -2.544 & 1.640 & & & \\
\hline Age & 0.006 & -0.012 & 0.025 & 0.002 & -0.004 & 0.008 \\
\hline Plot size (ha) & 1.484 & -2.085 & 4.857 & 0.448 & -0.674 & 1.503 \\
\hline Plowing & 0.331 & -0.188 & 0.848 & 0.102 & -0.059 & 0.279 \\
\hline Seed purchase & -0.243 & -0.759 & 0.277 & -0.076 & -0.252 & 0.086 \\
\hline Communal nursery & 0.122 & -0.482 & 0.728 & 0.038 & -0.150 & 0.229 \\
\hline IR64 & 0.499 & -0.140 & 1.160 & 0.133 & -0.045 & 0.370 \\
\hline Herbicide application & -0.596 & -1.153 & -0.051 & -0.184 & -0.381 & -0.016 \\
\hline Paddy yield (t ha ${ }^{-1}$ ) & 0.006 & -0.145 & 0.157 & 0.002 & -0.044 & 0.050 \\
\hline Straw removal & -0.258 & -0.894 & 0.377 & -0.079 & -0.285 & 0.120 \\
\hline Crop rotation & -1.497 & -2.440 & -0.627 & -0.452 & -0.700 & -0.214 \\
\hline Rho & -0.010 & -0.458 & 0.377 & & & \\
\hline Obs. & 128 & & & & & \\
\hline
\end{tabular}


increased in the fourth cropping season. Posterior means and $95 \%$ credible intervals for each estimate are shown in Table 4. Although spatial contiguity was detected for RYMV spread in the rice-farming community, spatial dependence $(\rho)$ was not detected for intra-plot RYMV aggravation. Without the spatial dependence, the constructed model was regarded as a probit model, which predicted that the probability of RYMV aggravation was relatively lower for plots treated with herbicide and subjected to crop rotation. The probability of aggravation was not affected by individual farmer variables or other agronomic practices. The marginal effects on aggravation caused by the changes in each independent variable are also shown in Table 4. The estimation indicated that herbicide application and crop rotation could decrease the probability of RYMV aggravation by $24.3 \%$ and $35.4 \%$, respectively.

Another spatial autoregressive model was constructed for model 4, in which RYMV aggravation was estimated based on whether or not the infection rate in the first season had increased in any of the subsequent cropping seasons. Posterior means, marginal effect, and 95\% credible intervals for each estimate are shown in Table 5. As we observed for model 3, spatial dependence $(\rho)$ was not detected in model 4. This probit model also detected "significantly" negative effects in herbicide application and crop rotation as was the case for the model 3. In this model, herbicide application and crop rotation were estimated to decrease the probability of RYMV aggravation by $18.4 \%$ and $45.2 \%$, respectively.

The probit models both predicted that herbicide application and crop rotation can mitigate intra-plot RYMV aggravation. In LMIS, selective herbicides were applied during rice production, whereas nonselective herbicides were used after harvest and/or before puddling. As nonselective herbicides might reduce the virus population by damaging wild reservoirs and infected rice stubble (Traoré et al. 2009), they may decrease the risk of intra-plot RYMV aggravation. During the maize phase of crop rotation, wet paddy soils are converted to dry uplands, so infected plant residues and rice stubble are kept dry for 3-4 months. RYMV infectivity diminishes when rice straw is kept dry for over 42 days (Uke et al. 2014). Crop rotation can reduce the virus population by drying infected rice straw and stubble during maize production.

\subsection{Agronomic measures against local RYMV outbreaks}

The present study identified specific reasonable agronomic measures that farmers should adopt to attenuate RYMV outbreaks. Our models estimated that crop rotation is the most effective modality for lowering the risk of inter-plot spread $(47.7 \%)$. As rice is traded at higher prices than maize in Tanzania (Sekiya et al. 2020), LMIS farmers have benefited from the price gap between rice and maize by implementing modern irrigation and advanced cultivation technologies (Sekiya et al. 2017). With the current price gap, complete replacement of rice with maize in crop rotation is impractical as a preventive measure, as farmers would incur large financial losses. Although plant residue removal is less efficacious than crop rotation as a defense against RYMV dissemination $(27.8 \%)$, it is relatively easier to practice and has minimal impact on revenue. The labor cost associated with plant residue removal is negligible in LMIS, as upland farmers from Mt. Kilimanjaro already collect it.

Replacement of IR64 with RYMV-resistant cultivars is about as effective as plant residue removal at inhibiting RYMV spread (26.9\%). TXD306 was often grown instead of IR64 and helped reduce the probability of inter-plot RYMV spread. The yield performance of TXD306 is apparently comparable or superior to that of IR64 (Sekiya et al. 2015). Though an initial seed purchase investment would be required, this cost should be lowered over time via self-seed multiplication. Thus, replacement of IR64 with TXD306 is a reasonable strategy for reducing inter-plot virus spread in a cost-effective manner.

When RYMV infection has already been established in a plot, crop rotation is most effective for reducing the probability of intra-plot RYMV aggravation (35.4\%). Nevertheless, crop rotation may cause farmers to incur substantial losses. Crop rotation may be recommended when the RYMV infection rate is already too high to permit a reasonable rice yield for the following season. In contrast, herbicide application is effective against intra-plot RYMV aggravation (24.3\%) and has minimal impact on yield; however, the herbicide cost must be calculated by considering the nature of herbicide and dose and frequency for its effective use which are still unknown in the present study. In addition to this financial cost, adverse effects of herbicide application on health and environment must be taken into consideration. Thus, rice farmers can likely lower the risk of inter-plot virus spread by removing plant residues and replacing cultivars. When disease severity is critical, herbicide application and crop rotation should be implemented to reduce the probability of intra-plot RYMV aggravation.

Our models identified candidate agronomic practices for the effective control of RYMV spread. However, controlled field trials are needed to establish causality, to better develop robust preventative measures. Future research should endeavor to identify the agents (insects, livestock, or others) involved in inter-plot virus spread and elucidate the mechanisms by which each agronomic practice lowers the risks of viral spread and intra-plot disease aggravation.

Wild reservoirs may be involved in both inter-plot and inter-seasonal (between cropping seasons) virus spread. Investigation into the roles of wild reservoirs in virus spread should also provide important information to aid in the development of preventative measures against 
RYMV outbreaks. While previous studies have reported the importance of rice seedbeds in intra-plot disease aggravation (Traoré et al. 2006; Traoré et al. 2009), the participation in a communal nursery was only queried in the current study. Further investigation into farmers' handling of their seedlings may elucidate more detailed mechanisms of intra-plot disease aggravation. The mechanism by which TXD306 reduces the probability of inter-plot RYMV spread merits further investigation, as this cultivar may itself be susceptible to RYMV (Uke et al. 2015; Hubert et al. 2017). Hence, the manner in which TXD306 inhibits inter-plot virus spread may not necessarily be an attribute of its genetic profile.

\subsection{Upscaling of spatial autoregressive analysis}

Our spatial autoregressive model, constructed from visual diagnoses of RYMV infection and farmer interviews, revealed spatial contiguity of RYMV spread in the rice farming community. The incorporation of spatial contiguity has proven to be more effective in the analysis of agronomic data than traditional statistical models, such as ordinary least squares (OLS). A spatial autoregressive model indicated that Phytophthora disease in bell pepper was associated with soil moisture gradients (Gumpertz et al., 1997). It also strongly related potato net necrosis with agronomic practices (Marsh et al. 2000). Spatial autoregressive models are currently used in precision agriculture investigations. Millet yield has been associated with soil macronutrient variability (Florax et al. 2002). Cotton yield responses to nitrogen and nematicide application rates were strongly influenced by landscape position (Anselin et al. 2004) and soil texture (Liu et al. 2015), respectively. However, these studies were limited to smaller-scale field experiments, possibly because of the difficulty in measuring explanatory variables such as soil moisture (Gumpertz et al., 1997), macronutrients (Florax et al. 2002), texture, and nematode populations (Liu et al. 2015) at larger scales. In contrast, our findings indicate that this powerful analytical tool can be upscaled from the experimental field to the farming community level by integrating the explanatory variables acquired via farmer interviews.

\section{Conclusion}

RYMV is a significant constraint on rice production in Sub-Saharan Africa. Viral transmission and dispersal models have been established, but the mechanisms underlying viral spread in farming communities and conditions causing local disease outbreaks remain unclear. We constructed spatial autoregression models using dependent RYMV infection rates and independent variables determined from field surveys and farmer interviews in
Tanzania. Inter-plot spread and intra-plot aggravation were associated with local agronomic practices implemented in each plot. We have demonstrated for the first time that this simple data sampling process facilitated model construction, allowing it to be expanded from the small-scale field experiment to the large-scale field survey level. Our study revealed close associations between RYMV outbreaks and agronomic practices and lays the foundation for improved control measures against RYMV. Nevertheless, the causal relationships remain to be clarified before efficacious RYMV outbreak control measures can be developed.

Supplementary Information The online version contains supplementary material available at https://doi.org/10.1007/s13593-022-00757-9.

Acknowledgements This study was conducted within the project framework of the "Technical Cooperation between Tanzania and Japan in Supporting Service Delivery Systems of Irrigated Agriculture (TANRICE, 2008-2012)". We thank Frederick Mawolle of the LMIS management office for data collection, as well as Emmanuel Mgonja of the Selian Agricultural Research Institute for providing us with the electron micrograph shown in Fig. 1.

Code availability Not applicable.

Authors' contributions Conceptualization, N.S., N.O., and T.N.; methodology, T.N.; formal analysis, TN; investigation, N.O., C.K., N.T, M.A.P., and K.T.N.; writing, N.S.; supervision, N.S., M.T., and K.T.N.; project administration, N.S.; funding acquisition, M.T.

Data availability The datasets generated and/or analyzed during the current study are available from the corresponding author on reasonable request.

\section{Declarations}

Conflict of interests The authors declare no competing interests.

Ethics approval Not applicable.

Consent to participate Verbal informed consent was obtained prior to each farmer's interview.

Consent for publication The authors affirm that human research participants provided informed consent for the publication of information disclosed in the interviews.

Open Access This article is licensed under a Creative Commons Attribution 4.0 International License, which permits use, sharing, adaptation, distribution and reproduction in any medium or format, as long as you give appropriate credit to the original author(s) and the source, provide a link to the Creative Commons licence, and indicate if changes were made. The images or other third party material in this article are included in the article's Creative Commons licence, unless indicated otherwise in a credit line to the material. If material is not included in the article's Creative Commons licence and your intended use is not permitted by statutory regulation or exceeds the permitted use, you will need to obtain 
permission directly from the copyright holder. To view a copy of this licence, visit http://creativecommons.org/licenses/by/4.0/.

\section{References}

Abo ME, Alegbejo MD, Sy AA, Misari SM (2000) An overview of the mode of transmission, host plants and methods of detection of rice yellow mottle virus. J Sustain Agric 17:19-36. https://doi.org/10. 1300/J064v17n01_04

Abubakar Z, Ali F, Pinel A, Traoré O, N'Guessan P, Notteghem JL, Kimmins F, Konaté G, Fargette D (2003) Phylogeography of rice yellow mottle virus in Africa. J Gen Virol 84:733-743. https://doi. org/10.1099/vir.0.18759-0

Anselin L (2010) Thirty years of spatial econometrics. Pap Reg Sci 89:325. https://doi.org/10.1111/j.1435-5957.2010.00279.x

Anselin L, Bongiovanni R, Lowenberg-DeBoer J (2004) A spatial econometric approach to the economics of site-specific nitrogen management in corn production. Am J Agric Econ 86:675-687

Bakker W (1970) Rice yellow mottle, a mechanically transmissible virus disease of rice in Kenya. Netherlands J Plant Pathol 76:53-63. https://doi.org/10.1007/BF01974433

Bakker W (1974) Characterization and ecological aspects of rice yellow mottle virus in Kenya. Agric Res Rep (Wageningen) 829:1-152

Besag JE (1972) Nearest-neighbour systems and the auto-logistic model for binary data. J R Stat Soc Ser B 34:75-83. https://doi.org/10. 1111/j.2517-6161.1972.tb00889.x

Besag J (1977) Some methods of statistical analysis for spatial data. Bull Int Stat Inst 47:77-92

Clark MF, Adams AN (1977) Characteristics of the microplate method of enzyme linked immunosorbent assay for the detection of plant viruses. J Gen Virol 34:475-483. https://doi.org/10.1099/0022-131734-3-475

Dellicour S, Vrancken B, Trovão NS, Fargette D, Lemey P (2018) On the importance of negative controls in viral landscape phylogeography. Virus Evol 4:1-9. https://doi.org/10.1093/ve/vey023

Fargette D, Fargette D, Abubakar Z et al (2004) Inferring the evolutionary history of rice yellow mottle virus from genomic, phylogenetic, and phylogeographic studies. Society 78:3252-3261. https://doi.org/10. 1128/JVI.78.7.3252

Fargette D, Konaté G, Fauquet C, Muller E, Peterschmitt M, Thresh JM (2006) Molecular ecology and emergence of tropical plant viruses. Annu Rev Phytopathol 44:235-260. https://doi.org/10.1146/ annurev.phyto.44.120705.104644

Fauquet C, Thouvenel J-C (1977) Isolation of the rice yellow mottle virus in Ivory Coast. Plant Dis Report 61:443-446

Florax RJGM, Voortman RL, Brouwer J (2002) Spatial dimensions of precision agriculture: a spatial econometric analysis of millet yield on Sahelian coversands. Agric Econ 27:425-443. https://doi.org/10. 1016/S0169-5150(02)00068-3

Gumpertz ML, Graham JM, Ristaino JB (1997) Autologistic model of spatial pattern of Phytophthora epidemic in bell pepper: effects of soil variables on disease presence. J Agric Biol Environ Stat 2:131156. https://doi.org/10.2307/1400400

Hubert J, Lyimo HJF, Luzi-Kihupi A (2017) Pathogenic variation and occurrence of multiple resistance-breaking rice yellow mottle virus strains in Tanzania. Am J Plant Sci 08:1820-1841. https://doi.org/ 10.4236/ajps.2017.88124

Ikegami K (1995) A study on technology transfer of paddy cultivation in the Kilimanjaro region, Tanzania. Mem Fac Agric Kinki Univ 28: $65-75$

Konate G, Traore O, Coulibaly MM (1997) Characterization of rice yellow mottle virus isolates in Sudano-Sahelian areas. Arch Virol 142: 1117-1124. https://doi.org/10.1007/s007050050146
Kouassi NK, N'Guessan P, Albar L et al (2005) Distribution and characterization of rice yellow mottle virus: a threat to African farmers. Plant Dis 89:124-133. https://doi.org/10.1094/PD-89-0124

LeSage JP, Pace RK (2009) Introduction to spatial econometrics. Chapman and Hall/CRC, New York

Liu Z, Griffin TW, Kirkpatrick TL, Monfort WS (2015) Spatial econometric approaches to developing site-specific nematode management strategies in cotton production. Precis Agric 16:587-600. https://doi.org/10.1007/s11119-015-9386-9

MAFC (Ministry of Agriculture Food Security and Cooperatives) (2009) National Rice Development Strategy. JICA (Japan International Cooperation Agency). https://www.jica.go.jp/english/our_work/ thematic issues/agricultural/card.html

Marsh TL, Mittelhammer RC, Huffaker RG (2000) Probit with spatial correlation by field plot : potato leafroll virus net necrosis in potatoes. J Agric Biol Environ Stat 5:22-36. https://doi.org/10.2307/ 1400629

N'Guessan P, Pinel A, Caruana ML et al (2000) Evidence of the presence of two serotypes of rice yellow mottle sobemovirus in Cote d'Ivoire. Eur J Plant Pathol 106:167-178. https://doi.org/10.1023/A: 1008792109954

Ndikuryayo C, Ochwo-Ssemakula M, Gibson P, Lamo J (2020) Resistance to rice yellow mottle virus and performance of selected improved rice genotypes in central Uganda. Crop Prot 129:105041. https://doi.org/10.1016/j.cropro.2019.105041

Peters D, Engels C, Sarra S (2012) Natural spread of plant viruses by birds. J Phytopathol 160:591-594. https://doi.org/10.1111/j.14390434.2012.01937.x

Pidon H, Ghesquière A, Chéron S, Issaka S, Hébrard E, Sabot F, Kolade O, Silué D, Albar L (2017) Fine mapping of RYMV3: a new resistance gene to rice yellow mottle virus from Oryza glaberrima. Theor Appl Genet 130:807-818. https://doi.org/10.1007/s00122-0172853-0

Pinel A, N'Guessan P, Bousalem M, Fargette D (2000) Molecular variability of geographically distinct isolates of rice yellow mottle virus in Africa. Arch Virol 145:1621-1638. https://doi.org/10.1007/ s007050070080

Rakotomalala M, Pinel-Galzi A, Albar L, Ghesquière A, Rabenantoandro Y, Ramavovololona P, Fargette D (2008) Resistance to rice yellow mottle virus in rice germplasm in Madagascar. Eur J Plant Pathol 122:277-286. https://doi.org/10.1007/s10658-008-9282-5

Rakotomalala M, Pinel-Galzi A, Mpunami A, Randrianasolo A, Ramavovololona P, Rabenantoandro Y, Fargette D (2013) Rice yellow mottle virus in Madagascar and in the Zanzibar Archipelago; island systems and evolutionary time scale to study virus emergence. Virus Res 171:71-79. https://doi.org/10.1016/j.virusres. 2012.10 .023

Sarra S (2005) Novel insights in the transmission of rice yellow mottle virus in irrigated rice. Dissertation, Wageningen University, Ph.D

Sarra S, Peters D (2003) Rice yellow mottle virus is transmitted by cows, donkeys, and grass rats in irrigated rice crops. Plant Dis 87:804-808. https://doi.org/10.1094/PDIS.2003.87.7.804

Sarra S, Oevering P, Guindo S, Peters D (2004) Wind-mediated spread of rice yellow mottle virus (RYMV) in irrigated rice crops. Plant Pathol 53:148-153. https://doi.org/10.1111/j.0032-0862.2004.00981.x

Savary S, Willocquet L, Pethybridge SJ, Esker P, McRoberts N, Nelson A (2019) The global burden of pathogens and pests on major food crops. Nat Ecol Evolution 3:430-439. https://doi.org/10.1038/ s41559-018-0793-y

Sekiya N, Khatib KJ, Makame SM, Tomitaka M, Oizumi N, Araki H (2013) Performance of a number of NERICA cultivars in Zanzibar, Tanzania: yield, yield components and grain quality. Plant Prod Sci 16:141-153. https://doi.org/10.1626/pps.16.141

Sekiya N, Shayo AC, Jacob MK, Oizumi N, Tomitaka M, Araki H (2015) Performance of four rice cultivars transplanted monthly over full 
year under irrigated conditions in Tanzania. Rice Sci 22:71-80. https://doi.org/10.1016/j.rsci.2015.05.008

Sekiya N, Tomitaka M, Oizumi N, Pyuza AG, Shayo RJ, Assenga AN, Iemoto T, Ishido K, Saiki Y, Tamura K, Nakamura T (2017) Importance of basic cultivation techniques to increase irrigated rice yields in Tanzania. Paddy Water Environ 15:847-859. https://doi. org/10.1007/s10333-017-0597-8

Sekiya N, Oizumi N, Kessy TT, Fimbo KMJ, Tomitaka M, Katsura K, Araki H (2020) Importance of market-oriented research for rice production in Tanzania. A review. Agron Sustain Dev 40:1-16. https://doi.org/10.1007/s13593-020-0611-1

Senthilkumar K, Tesha BJ, Mghase J, Rodenburg J (2018) Increasing paddy yields and improving farm management: results from participatory experiments with good agricultural practices (GAP) in Tanzania. Paddy Water Environ 16:749-766. https://doi.org/10. 1007/s10333-018-0666-7

Smyth GK, Chakraborty S, Clark R, Pettitt A (1992) A stochastic model for anthracnose development in Stylosanthes scabra. Phytopathology 82:1267-1272

Sõmera M, Sarmiento C, Truve E (2015) Overview on Sobemoviruses and a proposal for the creation of the family Sobemoviridae. Viruses 7:3076-3115. https://doi.org/10.3390/v7062761

Strauss D (1992) The many faces of logistic regression. Am Stat 46:321327. https://doi.org/10.1080/00031305.1992.10475920

Suvi WT, Shimelis H, Laing M (2019) Breeding rice for rice yellow mottle virus resistance in Sub-Saharan Africa: a review. Acta Agric Scand Sect B Soil Plant Sci 69:181-188. https://doi.org/10. 1080/09064710.2018.1523454
Traoré O, Traoré MD, Fargette D, Konaté G (2006) Rice seedbeds as a source of primary infection by rice yellow mottle virus. Eur J Plant Pathol 115:181-186. https://doi.org/10.1007/s10658-006-9004-9

Traoré MD, Traoré VSE, Galzi-Pinel A et al (2008) Abiotic transmission of rice yellow mottle virus through soil and contact between plants. Pakistan J Biol Sci 11:900-904. https://doi.org/10.3923/pjbs.2008. 900.904

Traoré O, Pinel-Galzi A, Sorho F, Sarra S, Rakotomalala M, Sangu E, Kanyeka Z, Séré Y, Konaté G, Fargette D (2009) A reassessment of the epidemiology of rice yellow mottle virus following recent advances in field and molecular studies. Virus Res 141:258-267. https://doi.org/10.1016/J.VIRUSRES.2009.01.011

Trovão NS, Baele G, Vrancken B, Bielejec F, Suchard MA, Fargette D, Lemey P (2015) Host ecology determines the dispersal patterns of a plant virus. Virus Evol 1:vev016. https://doi.org/10.1093/ve/vev016

Uke A, Tibanyendela N, Ikeda R, Fujiie A, Natsuaki KT (2014) Modes of transmission and stability of rice yellow mottle virus. J Plant Prot Res 54:363-366. https://doi.org/10.2478/jppr-2014-0054

Uke A, Tibanyendela N, Natsuaki KT et al (2015) Characterization of rice yellow mottle virus in north-eastern Tanzania. J Agric Sci Tokyo Nogyo Daigaku 60:116-126

Wilhelm S, de Matos MG (2013) Estimating spatial probit models in R. R J 5:130-143. https://doi.org/10.32614/rj-2013-013

Publisher's note Springer Nature remains neutral with regard to jurisdictional claims in published maps and institutional affiliations. 